\title{
Research on the mechanism of social enterprises' participation in social governance based on the concept of "three unity"
}

\author{
Tianmei Song \\ Xi 'an Peihua University.
}

Keywords: Social Business, Three Unity, Social Governance, Mechanism Research.

\begin{abstract}
Comrade Xi Jinping made the clear goal of China's social governance from 2020 to 2035, namely, "the pattern of modern social governance has basically taken shape, and the society is full of vitality, harmony and order". Influenced by economic and social factors, social enterprises have made positive contributions to solving social problems through commercial means. Based on the concept of "three unity", it is of great practical significance to explore the interaction between the government and social enterprises in social governance to form a new social governance system featuring benign interaction between government governance, social self-regulation and residents' autonomy.
\end{abstract}

\section{Introduction}

In the report to the 19th national congress of the communist party of China (CPC), special emphasis was placed on "building a pattern of social governance featuring joint efforts, common governance and Shared benefits". "Work sharing in the structure of social governance "is the" modern social governance structure ", it means that, from the past emphasis on the pursuit of economic growth to pay more attention to promoting people's all-round development and all-round social progress. The participation in main body from the pattern of government leading to that multiple subject party committee leadership, government responsibility, the social common governance, governance from top-down management in one direction to the government and the positive interaction of multiple subjects.

Influenced by economic and social factors, social enterprises have made positive contributions to solving social problems through commercial means. Based on the concept of "three unity", which is of great practical significance to explore the interaction between the government and social enterprises in social governance, to form a new social governance system featuring benign interaction between government governance, social self-regulation and residents' autonomy.

\section{Research review on the participation of social enterprises in social governance}

\subsection{Overview of research on social governance}

With the rise of the social welfare reform movement, the governance concept of "pluralistic participation and cooperative co-governance" began to attract attention and acceptance from various parties. This concept mainly includes three aspects: first, break through the dual opposition or single dominant structure between government and market, and start to pay attention to the role of social field in the management of state and social affairs. Second, we should attach importance to "participation in management", emphasizing the participation of diverse subjects in social affairs management, including social organizations and institutions. Third, pay attention to "multi-center governance" and "collaborative governance". In this management mode, the relationship of government, market and social subjects is no longer one way to dominate and be dominated, but to solve problems existing in the process of social development through consultation and cooperation on the basis of equality.

The proposal of "co-construction, co-governance and Shared social governance pattern" in China inherits and expands the wave of "cooperative governance" and "collaborative governance" emerging in the world, as well as continues and develops the policy innovation process from 
emphasizing social control to emphasizing public participation since new China. Not only that, the new expression of co-governance and sharing highlights the problem of co-governance at the representational level, enriches the content of the social governance pattern, and means that the social governance system is all-directional and the whole process is open to the society.

\subsection{Social enterprise research review}

Social enterprises have emerged with the transformation of western welfare states. In practice and theory, western countries have made comprehensive and in-depth studies on social enterprises. Different from traditional commercial enterprises or non-profit organizations. Social enterprises should emphasize the realization of economic goals and social goals at the same time. Foreign countries, especially western countries, have formed a very mature and complete system in the practice and research of social enterprises, which provides a very new method and perspective reference for the research of social enterprises in China.

\subsection{Overview of social enterprises' participation in social governance}

The social enterprise research and practice abroad, scholars attention and emphasis on the government for social enterprises to participate in social management and promote the development of the our country the study of social enterprises to participate in social governance promote mechanism is less, and in such aspects as laws, policies and measures of research, also lack the subject consciousness of the government to guide. It is of practical significance to explore the participation of social enterprises in social governance based on foreign research experience and the concept of "three in one".

\section{Research on the mechanism of social enterprises' participation in modern social governance}

Government, society and enterprises to participate in social governance as a social enterprise is lack of a relationship between three main body, which should maintain close cooperation and cooperative relations with work to provide legal guarantee for social enterprises to participate in social governance, policy incentives, promotion and personnel training and promotion mechanism to perfect the enterprise itself that is optimized, etc. Based on the tradition of government-led society in China, among the three main bodies involved in the social governance of Chinese social enterprises, the guiding, encouraging and guaranteeing roles of the government should be emphasized first, followed by the social recognition and support and the optimization and improvement of enterprises themselves. To perfect the promotion mechanism of social enterprises' participation in social governance and the promotion mechanism with the government as the core body is a reasonable choice in line with China's national conditions and the development of social enterprises.

\subsection{Analysis of the connotation of social governance pattern of co-construction, co-governance and sharing}

The report to the 19th national congress of the communist party of China (CPC) stressed the importance of "building a pattern of social governance featuring joint efforts, common governance and Shared benefits". The proposal of "co-construction, co-governance and sharing" has made a deployment of the pattern of modern social governance from the three aspects of basic basis, practical direction and fundamental purpose, indicating not only the methodology of social governance, but also the power source of social governance.

The co-construction, co-governance and sharing of social governance is an organic and unified relationship of mutual construction. Co-construction is the primary premise of co-governance and sharing. We should effectively integrate all social forces that can be mobilized, and make clearly the division of labor, power and responsibility. Co-governance is the common governance on the basis of co-construction. It is the concrete implementation and long-term maintenance of the division of labor and cooperation determined by the social governance construction program. 
Sharing is the inevitable result of co-construction and co-governance, and provides impetus and support for co-construction and co-governance.

\subsection{Value analysis of social enterprises' participation in social governance}

With the transformation of China's political economy, more and more poor, unemployed, education, environmental protection and social vulnerable groups need a flexible, development and professional organizations or institutions to support the interest protection and survival and development. The participation of social enterprises in social governance in China has created positive values for the government, society and enterprises.

The participation of social enterprises in social governance makes up the gap and gap in the field of social governance of the government, effectively solves social problems and improves political and social conflicts. Relieve the pressure of government social management and create conditions for the construction of service-oriented government and limited government. By mobilizing market resources to support social governance, it is conducive to the government's scientific, rational allocation and coordination of overall resources; Supporting sustainable development of social enterprises; It is helpful for the social subject's sense of ownership to improve and truly realize social self-management and self-improvement.

\subsection{Analysis on the relationship between social enterprises and government in social governance}

The practice of global social management has proved that it is impracticable or not good to rely only on the government to manage the society, nor is it realistic to rely only on the society to solve social problems and manage social life. The cooperation between the government and social enterprises is indispensable in the social governance of the "three unity".

Separation and cooperation are two directions in the evolution of the relationship between government and social enterprises. The precondition for the separation of government and social enterprises is that the government and social enterprises, as two independent subjects, participate in social governance and play the role of social governance independently in their own advantages. The cooperation between government and social enterprises requires the government and social enterprises to cooperate with each other in dealing with and solving social problems, give full play to their respective advantages and help each other to maximize the efficiency. How to balance the relationship between the government and social enterprises in the social governance of "three unity" is the key content of this research.

Social enterprises are sometimes involved in the absence of government functions and public opinions. As a new type of organization, social enterprises are also suspected by the society for their service ability. Social enterprises have the dual attributes of economy and public benefit. In the process of enterprise operation, conflicts and contradictions often occur in the balance between economic goals and social public benefit goals, which adversely affects the overall operation of social enterprises. The study on the participation of social enterprises in social governance can promote the sound development of social enterprises, thus improving the efficiency of public services, increasing employment opportunities, easing social conflicts and truly achieving the goal of benefiting the majority of the people.

\section{References:}

[1] Wang Ming and Zhu Xiaohong, Thesis of social enterprise,China Nonprofit Review,vol.2, pp.31,2010.

[2] Tiffany,From the third sector to social enterprises: concepts and methods,Comparative Economic \& Social Systems,vol.4,pp.89-93,2009.

[3] Wang Shiqiang,Official definition and identification criteria of social enterprises ,Research of Administration of NPOs,vol.6,pp.38-41,2012. 
[4] Yu Xiaomin and Ding Kaijie,Development path of social enterprises: international comparison and Chinese experience, Chinese Public Administration.vol.8, pp.61-65,2011.

[5] Chen Qingyun,Some problems in public management research,Journal of Renmin University of China.vol.1, pp.22-28,2001. 